\title{
TREE-RING INDICATORS OF FIRE IN TWO OLD-GROWTH COAST REDWOOD FORESTS
}

\author{
Allyson L. Carroll ${ }^{*}$, Stephen C. Sillett ${ }^{1}$, and Robert Van Pelt ${ }^{2}$ \\ ${ }^{1}$ Department of Forestry and Wildland Resources, Humboldt State University, \\ 1 Harpst Street, Arcata, California 95521, USA \\ ${ }^{2}$ School of Environmental and Forest Sciences, College of the Environment, \\ University of Washington, \\ Box 352100, Seattle, Washington 98195, USA \\ *Corresponding author: Tel.: +1-707-826-3935; e-mail: allyson.carroll@gmail.com \\ ABSTRACT

\section{RESUMEN}

\begin{abstract}
Fires that burn through forests cause changes in wood anatomy and growth that can be used to reconstruct fire histories. Fire is important in Sequoia sempervirens (D. Don) Endl. (coast redwood) forests, but fire histories are limited due to difficulties crossdating annual rings of this species. Here we investigated three fires $(1985,1999,2008)$ in two old-growth forests (Montgomery Woods State Natural Reserve and Landels-Hill Big Creek Reserve, California, USA) to quantify these responses via crossdated increment cores from lower trunks of 53 trees, including 10 that were climbed and cored at $10 \mathrm{~m}$ height intervals. Redwoods frequently responded to fire by producing anomalous growth during the fire year; 100 of 240 lower trunk cores recorded at least one anatomical indicator (i.e., intra-annual density fluctuation, faint latewood, resin, or scar). Following fire, radial growth decreased by $29 \%$ to $43 \%$ compared to the fire year. After accounting for climatic influences, radial growth was $27 \%$ to $32 \%$ lower than expected in the post-fire year
\end{abstract}

Los incendios que queman a través de bosques, producen cambios en la anatomía de la madera y en el crecimiento que pueden ser utilizados para reconstruir historias de fuego. El fuego es importante en los bosques de Sequoia sempervirens (D. Don) Endl. (sequoia roja costera), pero las historias de fuego son limitadas debido a dificultades para co-fechar anillos anuales de esta especie. Nosotros investigamos tres incendios (1985, 1999, 2008) en dos bosques maduros (Reserva Natural de Montgomery Woods State y Reserva de Landels-Hill Big Creek, California, EEUU) para cuantificar estas respuestas a través del co-fechado, mediante tarugos tomados en la parte inferior del tronco de 53 árboles, incluyendo 10 árboles en los cuales se hicieron tarugos en el tronco a distintas alturas a intervalos de 10 m. Los bosques de sequoia roja respondieron frecuentemente al fuego produciendo un crecimiento anómalo durante el año del incendio; 100 de 240 datos tomados de la parte inferior de los troncos mostraron al menos un indicador anatómico (i.e., fluctuación de la densidad intra-anual, leño tardío empalidecido, resina o cicatriz). Después del incendio, el crecimiento radial decreció de $29 \%$ a $43 \%$ comparado con el año en que ocurrió el fuego. Luego de tener en cuenta las influencias climáticas, el crecimiento radial fue de $27 \%$ a $32 \%$ más bajo que lo esperado en 
and declined to as low as $46 \%$ after three years. Growth suppression persisted for up to seven years after fire, followed by up to $40 \%$ higher than expected radial growth. Several of the climbed trees expressed disruption of incremental growth along the height gradient following fire. The 1985 event consistently generated stronger growth and anatomical responses than the 1999 and 2008 events, and showed a co-occurrence between faint latewood during the fire year and subsequent narrow or missing rings. We used post-fire low growth relative to drought combined with anatomical indicators to detect past fires, identifying five additional events at Landels-Hill Big Creek Reserve dating back to 1634 . Although other disturbances could have initiated these responses, our detection method enhances current capabilities for the spatiotemporal resolution of redwood fire histories via non-scar indicators on increment cores from living redwoods. el año post-fuego y declinó hasta el $46 \%$ tres años después. La supresión del crecimiento persistió hasta 7 años después del fuego, seguido luego por hasta un $40 \%$ más que el crecimiento radial esperado. Varios de los árboles tarugados en altura mostraron una disrupción del incremento del crecimiento a lo largo del gradiente de altura después del fuego. El evento de 1985 generó sistemáticamente respuestas en el crecimiento y respuestas anatómicas más evidentes que en los eventos de 1999 y de 2008, y mostraron una co-ocurrencia entre la palidez del leño tardío y subsecuentemente en el crecimiento de anillos, que resultaron más angostos o ausentes. Nosotros utilizamos el crecimiento lento post-fuego en relación a la sequía, combinado con indicadores anatómicos para detectar fuegos pasados, identificando cinco eventos adicionales en la Reserva de Landels-Hill Big Creek datando hacia el pasado hasta el año 1634. Aunque otros disturbios pudieron haber iniciado estas respuestas, nuestro método de detección refuerza las capacidades actuales para la resolución espacio-temporal de historias de fuego de la sequoia roja, a través de indicadores en datos de incremento de crecimiento en sequoias vivas mediante tarugos y no mediante cicatrices.

Keywords: California, coast redwood, dendrochronology, fire indicators, fire response, Sequoia sempervirens

Citation: Carroll, A.L., S.C. Sillett, and R. Van Pelt. 2018. Tree-ring indicators of fire in two oldgrowth coast redwood forests. Fire Ecology 14(1): 85-105. doi: 10.4996/fireecology.140185105

\section{INTRODUCTION}

Tree rings provide useful information about fire in Sequoia sempervirens (D. Don) Endl. (hereafter, redwood) forests. Remnant charcoal on trunks is visual evidence of fire (Sawyer et al. 2000), and ring counts of fire scars on redwood stumps extend over 1200 years (Fritz 1931). Fire is ecologically important and redwood has fire-adapted traits (e.g., thick bark, basal and epicormic sprouting), but the temporal and spatial variability of this dis- turbance across the redwood region is complex. Published fire histories for these forests indicate a wide range of fire-return intervals, from $>100$ yr to $<10$ yr within sub-regions, with several factors influencing this high variability (Lorimer et al. 2009). The north-south and coastal-interior climate gradients (Jacobs et al. 1985, Stuart and Stephens 2006) shape regional-scale differences, while localized topography and fuels can contribute to landscape-level variability (e.g., Heyerdahl et al. 2001). Human disturbances also impact fire 
regimes in the redwood region and include Native American burning, Euro-American ranching and logging, and fire exclusion (Greenlee and Langheim 1990, Brown and Baxter 2003, Anderson 2005, Stuart and Stephens 2006). Fire histories for redwood forests are less articulated than many other forests in the western United States due in large part to difficulty crossdating redwoods' annual rings (Fritz 1940).

Most redwood fire-return intervals derive from ring counts of undated tree-ring records (Jacobs et al. 1985, Stephens and Fry 2005, Jones and Russell 2015), and we know of only one published fire history based on crossdated samples from pre-Euro-American-settlement trees (Brown and Swetnam 1994). Redwood exhibits frequent discontinuous or missing rings (Fritz and Averill 1924, Carroll et al. 2014), declining radial growth with age that can result in ring widths $<0.1 \mathrm{~mm}$ (Sillett et al. 2010, Carroll et al. 2014), and anomalous growth near basal buttressing (Sillett et al. 2015). These characteristics limit crossdating, especially for older trees, which are targets for accessing tree rings to reconstruct fire histories. Centuries to millennium-scale crossdating along the latitudinal distribution has recently been achieved via intensive within-tree sampling of standing redwoods in old-growth forests, which improves crossdating confidence related to dendroclimatic variation (Carroll et al. 2014, 2017).

Reconstructing annually resolved fire histories in redwood forests has the added challenge of accessing evidence of past fires. Treering sampling near fire scars reveals distinctive cambium damage caused by fire with subsequent events affecting the same vulnerable areas (Arno and Sneck 1977, McBride 1983). Even though partial cross-sections can be collected from living trees to study fire history (Arno and Sneck 1977), such cuts from large redwoods would be unethical, like the case enunciated for Sequoiadendron giganteum (Lindl.) J. Buchholz (hereafter, giant sequoia) by Swetnam et al. (2009), limiting sampling of fire-scarred redwoods to stumps and fallen trees. Such sampling is the foundation of multi-millennial fire histories for giant sequoia (Swetnam et al. 2009) due to its comparatively straightforward crossdating (Carroll et al. 2014). While fire-resistant bark and extremely decay-resistant heartwood promote redwood longevity and allow centuries-old dead trunks to persist in old-growth forests, fire-scarred surfaces are often poorly preserved after bark loss and sapwood decay (Brown and Baxter 2003). The best fire-scar records may occur directly above the root crown (Brown and Swetnam 1994, Norman 2009), but the exclusion of partial cross-sections from living trees and difficulty in crossdating basal samples warrants examination of higher trunk positions.

Sudden changes in ring width in response to fire are well documented in the literature (Py et al. 2006, Lombardo et al. 2009, Swetnam et al. 2009, Margolis et al. 2011). A growth release (ring-width increase) may be attributed to reduced competition from damaged or killed neighboring trees that temporarily increased a tree's resource availability (Hartesveldt 1964, Lombardo et al. 2009). Giant sequoia, the closest relative of redwood, has a comparatively well known fire history, including many instances of growth release after fire (Swetnam et al. 1991, Brown et al. 1992, Swetnam 1993). Fire severity mediates growth response, and some low-severity fires do not reduce competition or increase soil nutrients enough to promote radial growth, while high-severity fires can cause major foliage damage and delay growth increases (Mutch and Swetnam 1995). Fuel accumulation due to fire suppression can influence growth responses, but large post-fire releases exist in pre-Euro-settlement tree-rings for giant sequoia (Caprio et al. 1994, Mutch 1994) and redwood (Brown and Swetnam 1994). The most common growth response to fire that has been observed in about a dozen fire-scarred redwood stumps near Redwood National Park 
in northern California, USA $\left(41^{\circ} 24 ' \mathrm{~N}\right.$, $\left.123^{\circ} 59^{\prime} \mathrm{W}\right)$, is an abrupt growth increase ranging from two years to several decades (Brown and Swetnam 1994). Conversely, some redwoods produce narrow or micro rings one to two years after a fire, with this ring-width variation being unrelated to climate (Brown and Swetnam 1994, Carroll et al. 2014). Loss of leaf area due to foliage scorch, heat-induced cambial damage, or heavy investment in reiteration (i.e., epicormic branching, basal sprouting) and roots following fire may cause such growth suppression (Brown 1991, 2013; Swezy and Agee 1991; Brown and Swetnam 1994; Seifert et al. 2017).

Anatomical indicators supplement scars for dating historical fires, often in conjunction with changes in ring width (Swetnam et al. 1991, Holz and Veblen 2009, Swetnam et al. 2009, Margolis et al. 2011). Redwood, giant sequoia, and other members of the Cupressaceae respond to injury by producing inducible traumatic resin ducts (TRD) in the xylem (Hudgins et al. 2004, Krokene et al. 2008), and fire-associated TRD occur up to $6 \mathrm{~m}$ above the ground on redwood trunks (Brown and Swetnam 1994). TRD provide evidence of fire in redwoods (Jones and Russell 2015), but the mechanics and variation of fire-induced TRD are poorly understood. Other anatomical reactions to heat exposure in conifers include resin soaking, discolored wood, and callus tissue formation (Smith et al. 2016). Intra-annual density fluctuations (IADFs) such as false rings and double latewood correspond with fire in both redwood and giant sequoia (Brown and Swetnam 1994, Swetnam et al. 2009, Jones and Russell 2015). IADFs result from disruption of normal xylogenesis during the growing season and reflect variations in environmental conditions often caused by climate (Vieira et al. 2010, De Micco et al. 2016).

Climate variation affects both tree growth and fire incidence on multiple time scales. Redwood inhabits a wide precipitation gradient, from rainforests in the north to drier for- ests in the south, although forests across the range experience dry summers with $<4 \%$ annual precipitation moderated by fog, which contributes hydrologic input and reduces water stress (Dawson 1998, Burgess and Dawson 2004, Van Pelt et al. 2016). Warm and dry summers constrain inter-annual redwood growth with a general trend of increasing sensitivity to drought and maximum temperature from north to south (Carroll et al. 2014). Most fires in the redwood region occur during dry late summer to early fall, as shown by twentieth century records (Gripp 1976) and sub-annual position of fire scars (Brown and Swetnam 1994, Brown and Baxter 2003, Jones and Russell 2015). In the North Coast Ranges of California, USA, fire often occurs during dry years (Skinner et al. 2009), and across the western USA, climate contributes to regionally synchronous fire years while terrain, fuels, and aspect influence landscape-level variability in fire severity (Swetnam 1993, Heyerdahl et al. 2001, Bigio et al. 2016). For the redwood region, fog and low cloud cover affect surface temperature variation (Iacobellis and Cayan 2013) and may temper the relationship between drought and fire for interior forests (Norman et al. 2009). Given that climate influences inter-annual growth and fire incidence, climate-induced variation should be considered when assessing indicators of fire in redwood forests.

In this study, we examine tree-rings in relation to fire in two old-growth redwood forests. Increment cores collected from live trees sample growth rings following fires in 1985, 1999, and 2008. Specifically, our goals are: 1) to document fire-associated ring features, including growth metrics and anatomical indicators; 2) to compare how fire indicators are expressed at different heights of standing trees; 3 ) to assess the effect of fire on growth after accounting for climate influences; and 4) to use growth and wood anomalies to detect past fire events in one forest. 


\section{METHODS}

\section{Study Area}

We sampled tree rings in two old-growth redwood forests-Montgomery Woods State Natural Reserve (MW) and Landels-Hill Big Creek Reserve (LH) - that were part of a 16plot network (Figure 1; Carroll et al. 2014, Sillett et al. 2015, Van Pelt et al. 2016). Central within the redwood distribution, MW is located $21 \mathrm{~km}$ northwest of Ukiah, California, USA, and $30 \mathrm{~km}$ from the Pacific Ocean at $39^{\circ} 14^{\prime} \mathrm{N}, 123^{\circ} 23^{\prime} \mathrm{W}$, at elevation $285 \mathrm{~m}$. Forest in the 1 ha MW plot was pure redwood canopy (i.e., $100 \%$ of live trees $>5 \mathrm{~cm}$ diameter at breast height [DBH]), including 15 trees $>107 \mathrm{~m}$ tall, in a flat valley (slope at study trees $\leq 1^{\circ}$ ) with plentiful access to water amidst steep slopes covered by much shorter woodland vegetation and chaparral (Van Pelt et al. 2016). Near the southern extreme of the redwood distribution, LH is located $61 \mathrm{~km}$ south of Monterey Bay, California, USA, and $2 \mathrm{~km}$ from the Pacific Ocean at $36^{\circ} 5^{\prime} \mathrm{N}, 121^{\circ} 35^{\prime} \mathrm{W}$, at elevation $165 \mathrm{~m}$. Forest in the 1 ha LH plot was redwood dominated (i.e., $63 \%$ of live trees $>5 \mathrm{~cm} \mathrm{DBH}$ ), including trees up to $80 \mathrm{~m}$ tall, but contained 13\% tanoak (Notholithocarpus densiflorus [Hook. \& Arn.] Manos) and 19\% California bay (Umbellularia californica [Hook. \& Arn.] Nutt.) (Van Pelt et al. 2016). LH is in a steeply incised canyon that abruptly transitions to chaparral toward ridgelines. The slopes at LH study trees ranged from $26^{\circ}$ to $70^{\circ}$ with a mean of $51^{\circ}$.

Both forests are characterized by cool, wet winters and warm, dry summers. Average annual precipitation at MW and LH was 1200 $\mathrm{mm}$ and $800 \mathrm{~mm}$, respectively, with $<2 \%$ falling during summer. Average summer maximum temperatures were higher at $\mathrm{MW}$ than at $\mathrm{LH}\left(29.3^{\circ} \mathrm{C}\right.$ vs. $\left.23.1^{\circ} \mathrm{C}\right)$, and average winter minimum temperatures were lower at $\mathrm{MW}$ than at $\mathrm{LH}\left(2.0^{\circ} \mathrm{C}\right.$ vs. $\left.3.9^{\circ} \mathrm{C}\right)$. Radial growth of redwoods at both forests is sensitive to

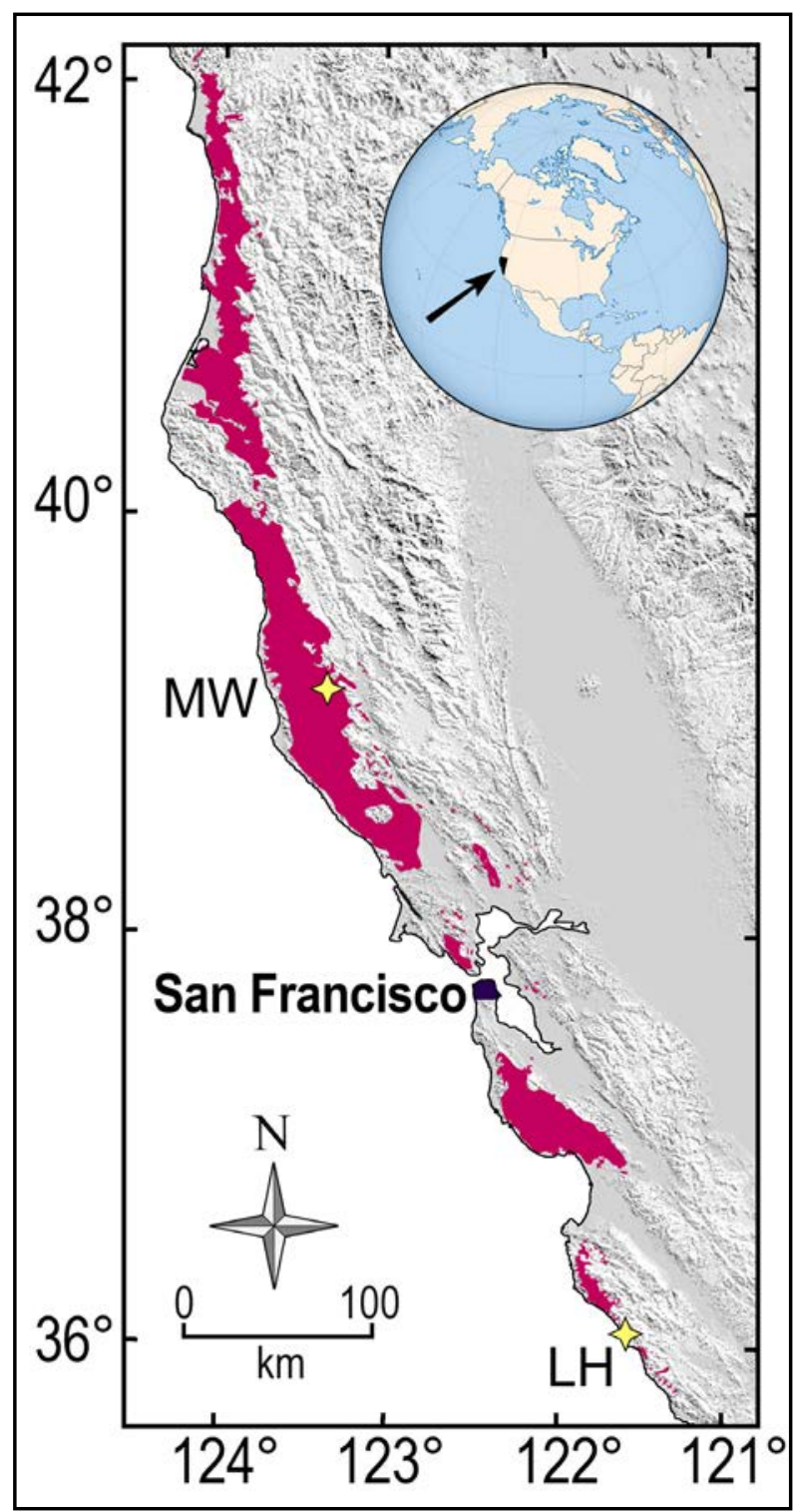

Figure 1. Geographic distribution of Sequoia sempervirens (shaded in pink) along the Pacific Coast of North America and study locations (yellow stars) at Montgomery Woods State Natural Reserve (MW) and Landels-Hill Big Creek Reserve (LH).

spring precipitation, summer temperature, and growing season soil moisture, with growth at LH limited earlier in the growing season than at MW (Carroll et al. 2014). LH has a particularly strong sensitivity to regional drought proxies compared to other redwood locations, including MW (Carroll et al. 2014). 


\section{Fire Events}

Three recent fires provided an opportunity to examine tree-ring responses to known events. Two low-severity to moderate-severity fires reached LH after lighting ignitions on 6 July 1985 (Gorda-Rat Fire) and 13 September 1999 (Kirk Complex Fire) (USGS 2016). We were unable to distinguish external indicators of fire between 1985 and 1999 because bark scorch could have occurred during either event. Lightning strikes on 20 June 2008 ignited 129 fires, and one of those fires, low-severity Orr Fire, reached MW. Bark of several redwoods was scorched and small patches of cambium were killed on several trees, but no known major crown dieback or tree death occurred in the plot.

\section{Tree-Ring Measurements}

During two collection periods (November 2010 and 2015 at MW, October 2011 and 2016 at LH), we sampled 42 trees and 248 series at MW, and 26 trees and 201 series at LH. Replicate (2 to 3 ) increment cores were obtained at breast height ( $\mathrm{BH}, 1.37 \mathrm{~m}$ ) and top of buttress (TB, $3.4 \mathrm{~m}$ to $12.4 \mathrm{~m}$ above ground at MW, and $2.5 \mathrm{~m}$ to $8.6 \mathrm{~m}$ above ground at $\mathrm{LH}$ ) from large redwoods in each plot (34 trees $94 \mathrm{~cm}$ $f$-DBH to $481 \mathrm{~cm} f$-DBH up to $112 \mathrm{~m}$ tall at MW, 23 trees $93 \mathrm{~cm} f$-DBH to $334 \mathrm{~cm} f$-DBH up to $80 \mathrm{~m}$ tall at $\mathrm{LH}$, where $f-\mathrm{DBH}$ is the functional $\mathrm{DBH}$ for non-round bases using footprint analysis; Van Pelt et al. 2016). Two cores were generally taken at each position (BH and TB) from opposite sides and away from fire scars or abnormalities as dictated by related research goals. Eleven smaller trees (8 at MW, 3 at LH) had minimal buttressing and round trunks at $\mathrm{BH}$ or, if standing on a steep slope, the high point of ground. These trees each received two cores at that height. We measured bark thickness as radial distance from cambium to a tape measure wrapped around the trunk, where cambium was located by inserting a probe into the core hole. We also cored a subsample of five trees of various sizes in each plot at $10 \mathrm{~m}$ intervals to quantify incremental growth along the height gradient. In all trees, $\mathrm{BH}$ and $\mathrm{TB}$ cores were relatively young, often $<100$ years, but cores from $10 \mathrm{~m}$ and higher captured longer time series (up to $>1000$ yr; Carroll et al. 2014). Samples and measurements inaccessible from the ground were obtained by climbers on rope (Sillett et al. 2015). Crossdating and excluding cores that did not reach fire years resulted in a final sample size of 31 trees at $\mathrm{MW}$ and 22 trees at LH.

We prepared, surfaced, measured, and crossdated all cores utilizing published methods and tree-ring chronologies for $\mathrm{MW}$ and LH (Carroll et al. 2014), combining visual crossdating techniques of listing marker years and staggered correlation analysis in COFECHA software (Holmes 1983) for ring widths measured to $0.001 \mathrm{~mm}$ (WINDENDRO software v.2009b, Régent Instruments Inc., Québec, Canada). Due to the inherent difficulty of crossdating redwood, we classified years based on confidence in annual resolution (Carroll et al. 2014) and excluded from analysis time series and trees for which at least moderate confidence was not obtainable. In addition to measuring ring width, we examined growth rings produced during fire years and five subsequent years for anatomical indicators of this disturbance, noting occurrences of IADFs, faint latewood, resin, and scars. IADFs were distinguished by a band of latewood-like cells in the earlywood or earlywood-like cells in the latewood (De Micco et al. 2009). Faint latewood was visually determined by the light coloration of the latewood compared to the normal appearance of surrounding rings, similar to the identification of light rings based on hardly visible or lighter latewood due to thinner cell walls (Liang and Eckstein 2006). Occurrence of resin included both TRD noted by cell structure and infused resin noted by coloration. Fire scars were identified by ring separation, darker coloration, and subsequent large rings associated with occlusion of wounds. 


\section{Computing Growth Increments}

For smaller trees with round bases, we computed radial growth simply as average ring widths of replicate cores, and for the large trees with complex bases, we combined all available information between $\mathrm{BH}$ and $\mathrm{TB}$ to express growth as trunk-level ring width. Depending on the height and complexity of buttressing, we quantified functional diameters at 1 to 7 additional heights between $\mathrm{BH}$ and TB. Existing equations allowed prediction of bark thickness at all heights (Sillett et al. 2015: Appendix C), but some trees had unusually thick or thin bark for a given diameter. We used a four-step algorithm to accommodate such treeto-tree variation before computing growth increments. First, we averaged measured and predicted values to estimate bark thickness at $\mathrm{BH}$ and TB. Second, we computed a correction factor at each height by dividing estimated values by predicted values. Third, we used linear interpolation to compute correction factors for intervening measurement heights. Fourth, we multiplied correction factors by predicted values to estimate bark thickness at intervening heights. We then subtracted bark thickness from total radius (i.e., half of functional diameter) to compute wood radius. After interpolating ring widths at measurement heights between $\mathrm{BH}$ and $\mathrm{TB}$, time series of trunk wood volume and cambium area were calculated as conic frusta starting with year of measurement and continuing via subtraction of ring widths as far back as dendrochronology allowed. We computed wood volume increment by subtracting previous values from subsequent values and then expressed radial growth ( $\left.\mathrm{mm} \mathrm{yr}^{-1}\right)$ as the specific volume increment (wood volume increment divided by average cambium area at start and end of each year).

To quantify wood production along the vertical gradient, we computed wood volume increment for main trunks of climbed trees in each plot. Above TB, we used linear interpolation to compute ring widths at measurement heights between core samples. Below $\mathrm{BH}$, we calculated ring width as the average of ring width at $\mathrm{BH}$ and the ring-width:wood radius ratio at $\mathrm{BH}$ multiplied by wood radius at lower height. This procedure accounted for wood investment in buttress formation while maintaining a consistent rate of taper change (Sillett et al. 2015). To visualize vertical growth patterns, we converted ring widths to cross-sectional areas at each height by sequentially subtracting wood cross-sections (e.g., 2014 cross-section subtracted from 2015 cross-section yielded 2015 ring area). Across all measurement heights for each tree, we regressed ring area against wood radius and computed the coefficient of determination $\left(\mathrm{R}^{2}\right)$ for each year. These ring-area versus radius correlations tended to be positive and strong $\left(\mathrm{R}^{2}>\right.$ $0.9)$ most years as a consequence of geometry, but when disruptions in ring taper (e.g., missing or abnormally large rings) occurred for whatever reason, $\mathrm{R}^{2}$ values dropped precipitously. We identified anomalous years in ring-area versus radius correlation time series (hereafter, taper anomalies) by expressing each year as the difference between preceding and subsequent 5-year means, and then standardizing values by standard deviates across the full time series for each tree.

\section{Dendroclimatic Analysis}

Because climate is a major driver of ringwidth variation, we accounted for climatic influence on radial growth to isolate potential fire effects. Climate variables considered for modeling radial growth included monthly and seasonal precipitation, maximum temperature, minimum temperature, Palmer Drought Severity Index (PDSI), and streamflow. We used PRISM (Parameter-elevations Regressions on Independent Slopes Model, LT81) data at 800 $\mathrm{m}$ resolution for precipitation and temperature (PRISM Climate Group 2016) and PRISMbased WestWide Drought Tracker data at $4 \mathrm{~km}$ resolution for PDSI (Western Regional Climate Center 2017). PDSI incorporates tem- 
perature and precipitation and serves as a proxy for surface soil moisture (Dai et al. 2004). For streamflow information, we acquired United States Geological Survey (USGS) monthly discharge data for the Russian River near Ukiah, California (USGS site 11461000) and the Big Sur River near Big Sur, California (USGS site 1143000), located within $25 \mathrm{~km}$ of MW and LH, respectively. To identify the most relevant climate variables influencing lower-trunk growth, we regressed average radial growth (10-tree replication: LH 1950 to 2016 and MW 1953 to 2015) at each location with monthly and seasonal climate variables. We then examined correlations between radial growth and climate, used stepwise regression in JMP 13 (SAS Institute Inc., Cary, North Carolina, USA) to select the best climate variable or variables for predicting radial growth of lower trunks, and used residuals as a metric of non-climatic effects on growth.

\section{Detecting Past Fires}

Five trees cored at $10 \mathrm{~m}$ intervals, two trees partially cored above TB, as well as three remnant wood samples at LH provided hundreds of years of tree-ring history to examine for fire indicators. The strong growth sensitivity to a single climate variable with a reliable long-term proxy (PDSI) and documented postfire narrow rings (Carroll et al. 2014) made LH suitable for analysis beyond the time period of historical climate records. For multi-century PDSI data representative of $\mathrm{LH}$, we obtained reconstructed PDSI for grid point $36\left(37^{\circ} 30^{\prime} \mathrm{N}, 122^{\circ} 30^{\prime} \mathrm{W}\right.$; Cook and Krusic 2004). At LH, we created a ring index aligned with earlier methods (Carroll et al. 2014) and updated with new samples. We generated tree-level chronologies using only series with high crossdating confidence and $\geq 50$-year length, then detrended in ARSTAN (Cook 1985) with a 32-year spline. Tree-level chronologies were combined into one plot-level chronology, and the standard version was used for analysis. Crossdating the earliest years of one LH remnant sample that had no comparable redwood series before 1653 was confirmed using a blue oak (Quercus douglasii Hook. \& Arn.) chronology composed of the four nearest locations from Stahle et al. (2013) with data retrieved from the International Tree Ring Data Bank (NOAA 2017). We obtained remnant wood samples cut as sections from fallen redwoods on or near the plot in the same drainage.

To identify possible post-fire years, we regressed tree-ring and PDSI indices and used residuals to isolate years with lower than expected growth. We divided the period of analysis into two series based on replication $(<5$ trees 1540 to $1721, \geq 5$ trees 1722 to 2003). Years with anomalously low radial growth (residuals $<2$ SD below mean) in each series were then examined for anatomical indicators of fire, including the subsequent five rings.

\section{RESULTS}

\section{Anatomical Indicators of Fire}

The three fire years were frequently associated with wood anomalies, as 100 of 240 (41.7\%) crossdated lower-trunk rings recorded at least one indicator (Figure 2). At the tree-level, an indicator was present for the fire year on at least one core for 48 of $75(64 \%)$ occurrences. The 1985 fire at LH was the most impactful with $87.5 \%$ of cores and $100 \%$ of trees recording at least one indicator (Table $1)$. The most frequent indicator was faint latewood in the 1985 ring (65.6\% of rings, Figure 2B), but faint latewood occurred on $<8 \%$ of the 1999 and 2008 rings. Mean ring width in 1986 was significantly smaller when 1985 had faint latewood $(0.244 \mathrm{~mm}$ versus $1.315 \mathrm{~mm}$; $\left.t_{26}=4.73, P<0.001\right)$, and of 42 cores with faint latewood in 1985, 30 had a missing (i.e., locally absent) ring in 1986. IADFs noted as latewood-like cells in the earlywood corresponded with summer fires (1985 and 2008; Figure 2C and 2D), and earlywood-like cells in the latewood occurred for all three fires 


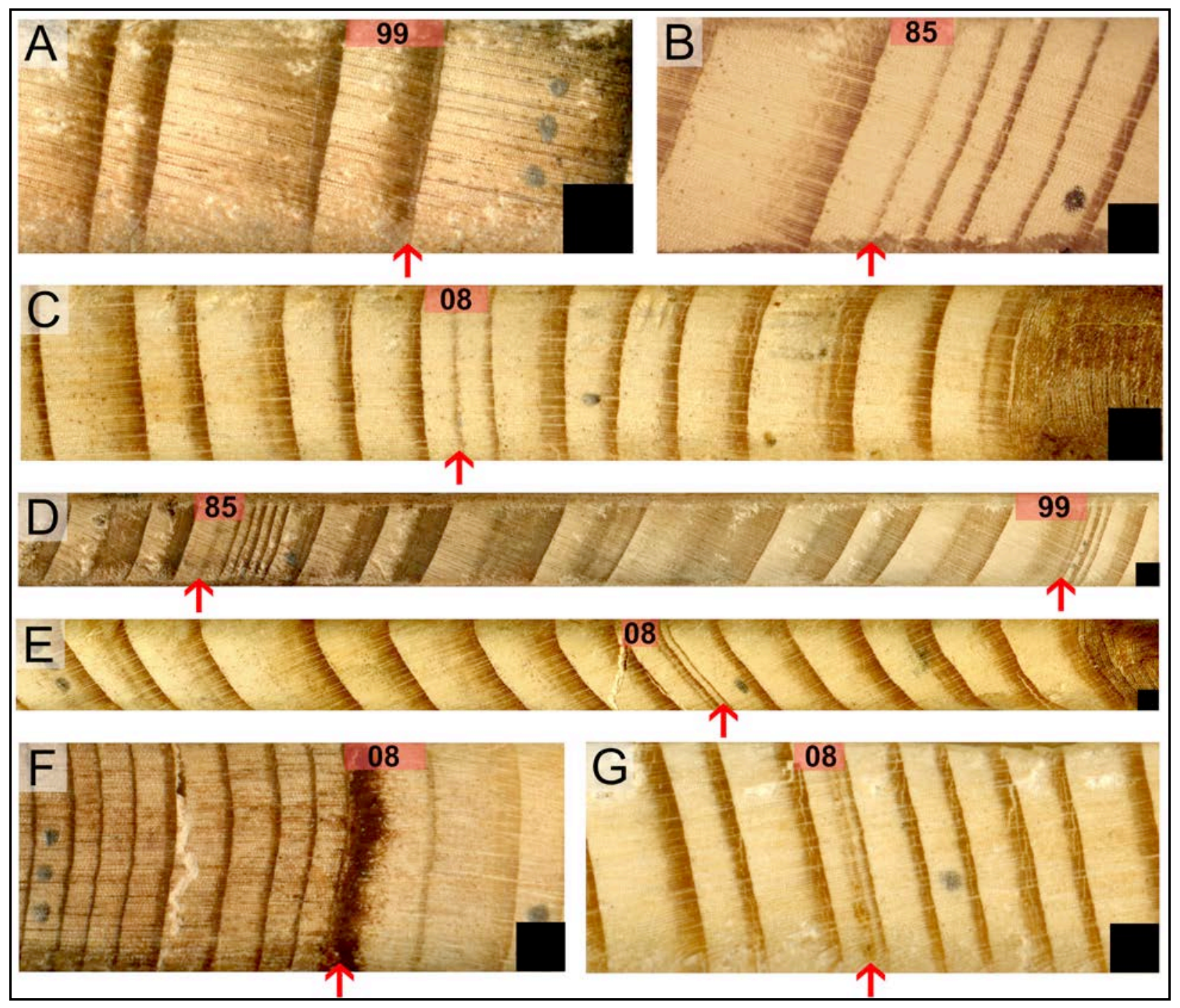

Figure 2. Anatomical indicators associated with fire years for redwoods in two old-growth forests at Montgomery Woods State Natural Reserve and Landels-Hill Big Creek Reserve. All samples from crossdated lower-trunk cores. Growth proceeds from left to right. Red boxes span annual ring of fire years abbreviated in black text $(85=1985,99=1999,08=2008)$. Black boxes in lower right corners cover 1 $\mathrm{mm}^{2}$. Red arrows indicate: A) intra-annual density fluctuation (IADF) in latewood of 1999, B) faint latewood in 1985 with subsequent missing ring for 1986, C) IADF in earlywood of 2008 for June fire, D) IADF in earlywood of 1985 for July fire with reduced growth 1986 to 1989, IADF in latewood of 1999 with subsequent smaller rings for 2000 and 2001, E) post-fire narrow ring after 2008, F) infused resin in 2008, and G) traumatic resin ducts and IADF in 2008.

(Figure 2A, 2D, and 2G). Only two of 240 rings showed fire scars because our sampling avoided "catfaces." Resin occurred on $\leq 3.1 \%$ of lower-trunk cores for fire years (Table 1) but was the most common indicator over the subsequent five years with a maximum of eight occurrences after the 1999 fire. Growth anomalies occurred intermittently regardless of fire, with $1.2 \%$ and $2.4 \%$ of cores showing an indicator for a randomly generated year at MW and LH, respectively.

Anatomical indicators on the fire year were observed at various heights on trunks of nine climbed trees (Figure 3). Among eight trees with indicators for the fire year at or below $\mathrm{TB}$, five also had indicators higher above the 
Table 1. Anatomical indicators present (\%) on annual ring of fire years for redwoods in two old-growth forests at Montgomery Woods State Natural Reserve (MW) and Landels-Hill Big Creek Reserve (LH). Analysis includes lower-trunk cores with crossdated fire years. Indicator tallied for trees if present on at least one core. If at least one indicator is present, it is tallied for "any indicator" category. IADF means intra-annual density fluctuation.

\begin{tabular}{|c|c|c|c|c|c|c|}
\hline \multirow[b]{2}{*}{ Anatomical indicators } & \multicolumn{2}{|c|}{$\begin{array}{c}\text { Gorda-Rat Fire } \\
\text { Jul } 1985 \text { - LH }\end{array}$} & \multicolumn{2}{|c|}{$\begin{array}{l}\text { Kirk Complex Fire } \\
\text { Sep } 1999 \text { - LH }\end{array}$} & \multicolumn{2}{|c|}{$\begin{array}{c}\text { Orr Fire } \\
\text { Jun } 2008 \text { - MW }\end{array}$} \\
\hline & Cores & Trees & Cores & Trees & Cores & Trees \\
\hline Any indicator (\%) & 87.5 & 100 & 22.9 & 50.0 & 26.4 & 48.4 \\
\hline IADF (\%) & 37.5 & 59.1 & 15.7 & 31.8 & 17.9 & 35.5 \\
\hline Faint latewood (\%) & 65.6 & 81.8 & 7.1 & 18.2 & 7.5 & 16.1 \\
\hline $\operatorname{Resin}(\%)$ & 3.1 & 9.1 & 0.0 & 0.0 & 2.8 & 9.7 \\
\hline \multirow[t]{2}{*}{ Scar $(\%)$} & 0.0 & 0.0 & 1.4 & 4.5 & 0.9 & 3.2 \\
\hline & \multicolumn{2}{|c|}{$n=64$ cores, 22 trees } & \multicolumn{2}{|c|}{$n=70$ cores, 22 trees } & \multicolumn{2}{|c|}{$n=106$ cores, 31 trees } \\
\hline
\end{tabular}

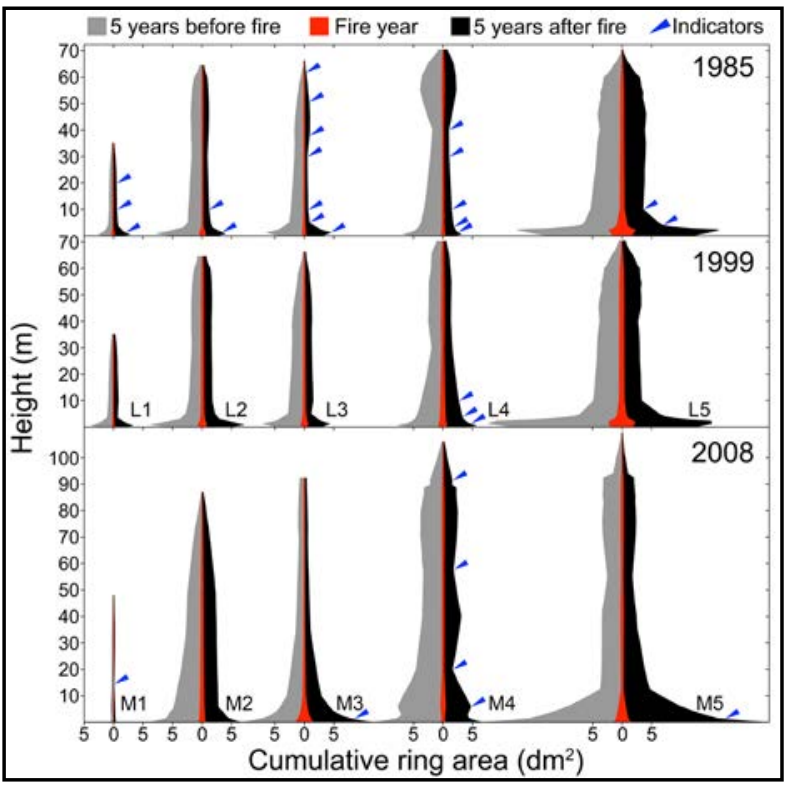

Figure 3. Ring area profiles for ten climbed trees in two locations with respect to three fires (1985 and 1999 at Landels-Hill Big Creek Reserve, 2008 at Montgomery Woods State Natural Reserve). Cumulative ring areas indicated by colors are directly proportional to trunk wood volume increments over 11 years, centered on fire year. Blue arrows show observed heights of tree-ring indicators (i.e., intra-annual density fluctuations, faint latewood, resin) during fire year. Tree name on lower right, only crossdated trees included. ground. At LH, all five trees had indicators on the 1985 ring at or above $10 \mathrm{~m}$. Tree 3 at LH had indicators on the 1985 ring at seven heights up to $61.8 \mathrm{~m}$, most of which were faint latewood. Among indicators on the five rings following the 1985 fire, 31 of 43 were resin. Only one climbed tree at LH had indicators on the 1999 ring, all at or below $10 \mathrm{~m}$, but all five had resin within the subsequent five years, especially 2001 (14 of 81 cores). Tree 4 at MW had indicators on the 2008 fire year at four heights up to $91.5 \mathrm{~m}$, but no indicators in subsequent years.

\section{Growth Increments}

Lower-trunk radial growth decreased in the years following each fire, with trees producing some of the smallest rings since 1900 (Figure 4). At LH, radial growth plummeted after 1985 and did not recover for several years. Post-fire years 1986 to 1988 produced the smallest rings $(0.60 \mathrm{~mm}$ to $0.70 \mathrm{~mm})$ of the series, and 1986 had the largest decrease $(43.2 \%)$ in growth compared to the previous year. Post-fire year 2000 produced the seventeenth smallest ring but had the third largest decrease (37.7\%) in growth. At MW, the 2009 ring $(0.83 \mathrm{~mm})$ was the second smallest of the 


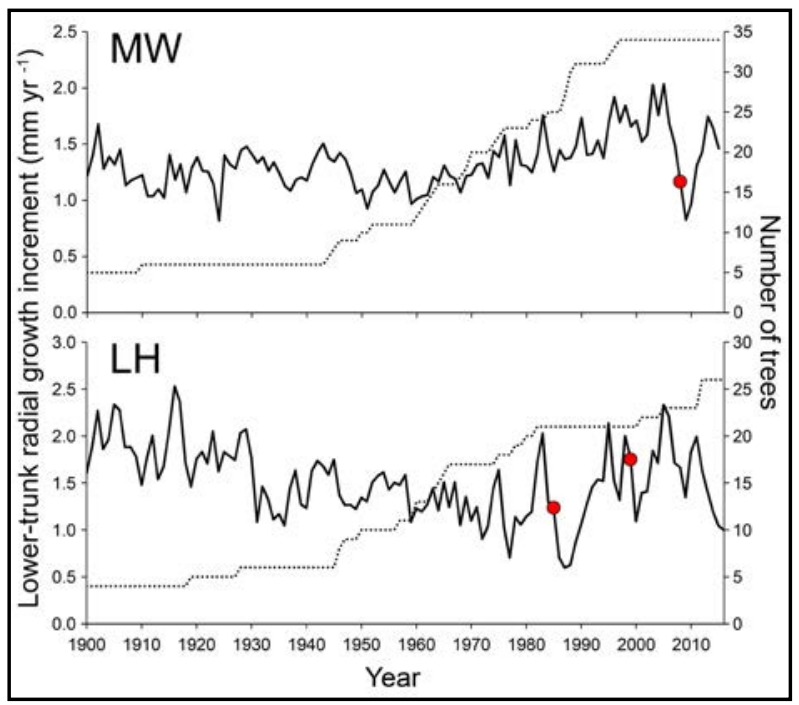

Figure 4. Lower-trunk radial growth increment and sample depth for redwoods at Montgomery Woods State Natural Reserve (MW; 1900 to 2015) and Landels-Hill Big Creek Reserve (LH; 1900 to 2016) using all crossdated cores at or below buttress. Red circles mark fires at 2008 for MW, and 1985 and 1999 for LH.

time series, behind only 1924 (0.82 mm), which had the lowest average growing season (March to October) PDSI. The year 2009 ranked twenty-sixth for PDSI, but it had the largest decrease in ring width $(29.0 \%)$ compared to the previous year. These post-fire low growth rings were distinctive and easily noted during visual crossdating (Figure 2D and 2E).

As was evident with lower-trunk radial growth, whole-trunk wood volume increment of climbed trees was $26 \%$ to $35 \%$ lower for the five years after fire compared to the five years before fire (1985, $T_{4}=3.19, P=0.018$; 1999, $T_{4}=3.19, P=0.017 ; 2008, T_{4}=2.15, P$ $=0.049$ ). While the vertical pattern of wood production was similar in some trees before and after fires, other trees exhibited disruptions in ring taper. These taper anomalies were $\geq 2$ standard deviations in trees 1 and 4 at MW, and trees 3, 4, and 5 at LH after the 1985 fire. The 1999 fire at LH caused the least disruption with only one tree (tree 3) having a taper anomaly $>1$ standard deviation.

\section{Dendroclimatic Analysis}

Accounting for climatic influences on lower-trunk radial growth helped to quantify fire effects. At MW, three climate variables (i.e., May PDSI, September streamflow, October precipitation) together explained $40.5 \%$ of radial growth variation, and at $\mathrm{LH}$, the single predictor of mean April to August PDSI explained $42.2 \%$ of the variation (Table 2 ). Residual differences between measured and predicted growth were greatest in years following fire at both locations (Figure 5). At MW, radial growth was $30.4 \%$ lower than expected in 2009, and residual differences were negative until 2013. At LH, radial growth was $27.4 \%$ lower than expected in 1986, decreasing to $45.8 \%$ in 1988 , and residual differences were negative until 1992, when radial growth was $40.4 \%$ higher than expected. The 1999 event showed a similar pattern with negative post-

Table 2. Equations to predict lower-trunk growth increment based on monthly climate parameters for redwoods in two old-growth forests at Montgomery Woods State Natural Reserve (MW) and Landels-Hill Big Creek Reserve (LH). Predictors (V1 to V3) followed by regression coefficients ( $a$ to $d$ ), sample size $(n)$, goodness of fit $\left(\mathrm{R}^{2}\right)$, and form of equation. PDSI = Palmer Drought Severity Index, str = mean streamflow discharge, $\mathrm{pcp}=$ total precipitation.

\begin{tabular}{|c|c|c|c|c|c|c|c|c|c|c|}
\hline Plot & V1 & V2 & V3 & $a$ & $b$ & $c$ & $d$ & $n$ & $\mathbf{R}^{2}$ & Form \\
\hline MW & $\begin{array}{l}\text { May } \\
\text { PDSI }\end{array}$ & $\begin{array}{l}\text { Sep } \\
\text { str }\end{array}$ & $\begin{array}{l}\text { Oct } \\
\text { pcp }\end{array}$ & 0.022 & 0.104 & -0.001 & 1.234 & 63 & 0.405 & $a \mathrm{~V} 1+b \mathrm{~V} 2+c \mathrm{~V} 3+d$ \\
\hline $\mathrm{LH}$ & $\begin{array}{c}\text { Apr to } \\
\text { Aug PDSI }\end{array}$ & & & 0.063 & 1.344 & & & 67 & 0.422 & $a \mathrm{~V} 1+b$ \\
\hline
\end{tabular}




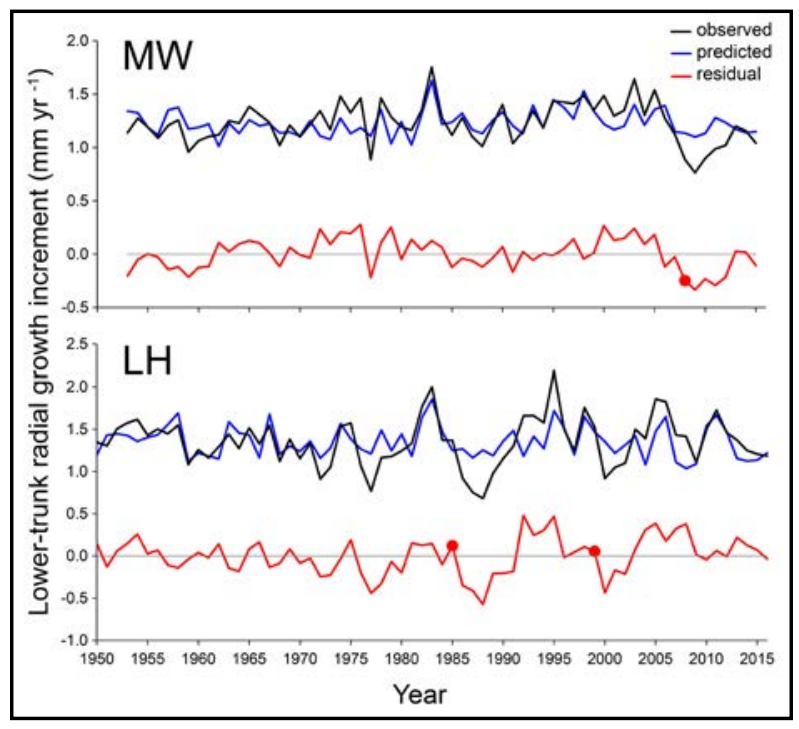

Figure 5. Lower-trunk radial growth increment for ten redwoods at Montgomery Woods State Natural Reserve (MW; 1953 to 2015) and Landels-Hill Big Creek Reserve (LH; 1950 to 2016). Black lines represent calculated growth increment using crossdated cores at or below buttress. Blue lines represent the predicted growth increment based on the strongest climate drivers. Red lines represent the residuals centered on zero. Red circles mark fires at 2008 for MW, and 1985 and 1999 for LH.

fire residual differences (i.e., radial growth $32.2 \%$ lower than expected in 2000) lasting until 2003 and followed by up to $36.7 \%$ higher than expected radial growth until 2010.

\section{Detecting Past Fires}

Linear regression of the LH ring-width index against reconstructed PDSI generated a multi-century time series of residual values to examine for evidence of fire (Figure 6). The LH ring index dated from 1540 to 2016, extending the previous LH chronology (Carroll et al. 2014) by 113 years. Crossdating remnant wood samples was supported by significant correlations between standardized LH and blue oak chronologies $(\mathrm{r}=0.28, P<0.001$ for 1653 to $1999 ; \mathrm{r}=0.27, P=0.004$ for 1540 to 1652). The PDSI reconstruction explained $23.2 \%$ of ring width variation, highlighting 14 years in which radial growth was at least 2 standard deviations (SD) below the mean (Figure 6). At LH, the 1985 and 1999 fires were both identified, and 1986 had the largest residual difference between measured ring width and predicted ring width (-3.7 SD), followed by $2000(-3.0 \mathrm{SD})$. We refined the list to eight events after combining sequential years with unusually small ring widths (e.g., 1986 and 1987). Low-growth years 1634 and 1977 were categorized as potential fire years rather than the previous year due to associated anatomical indicators. While growth releases were not used to detect past fires, the highest ring-width indices occurred in post-event windows for 1647 (3.3 SD above the mean) and 1869 (4.1 SD above the mean) (Figure 6).

In addition to the known fires, at least one anatomical indicator was observed in five of the six newly identified years and their subsequent rings (Figures 7, 8, and 9). Potential fire year 1841 and subsequent years had indicators on nine of ten trees (Figures 7 and 9D), and of the 23 indicators on subsequent rings, 17 were resin (Figure 8). Resin was the only indicator on potential fire year 1864 (4 of 40 cores on 3 trees) with resin also documented several years after the event (Figures 7, 8, and 9C). Indicators for potential fire years 1900 and 1977 were less frequent but included resin and abnormal growth for the fire year and resin for subsequent years (Figures 7 and 8). One remnant sample from outside the plot had TRD (Figure 9E) and faint latewood in the 1977 ring, and a strong band of TRD was observed in the 1634 ring of another (Figure 9F).

\section{DISCUSSION}

Redwoods growing in two old-growth forests show responses to fires in 1985, 1999, and 2008, with anomalous ring structures and changes in radial growth. While several of these features are documented in redwoods ancillary to stump-level fire scars (Brown and Swetnam 1994), we quantified indicators in 


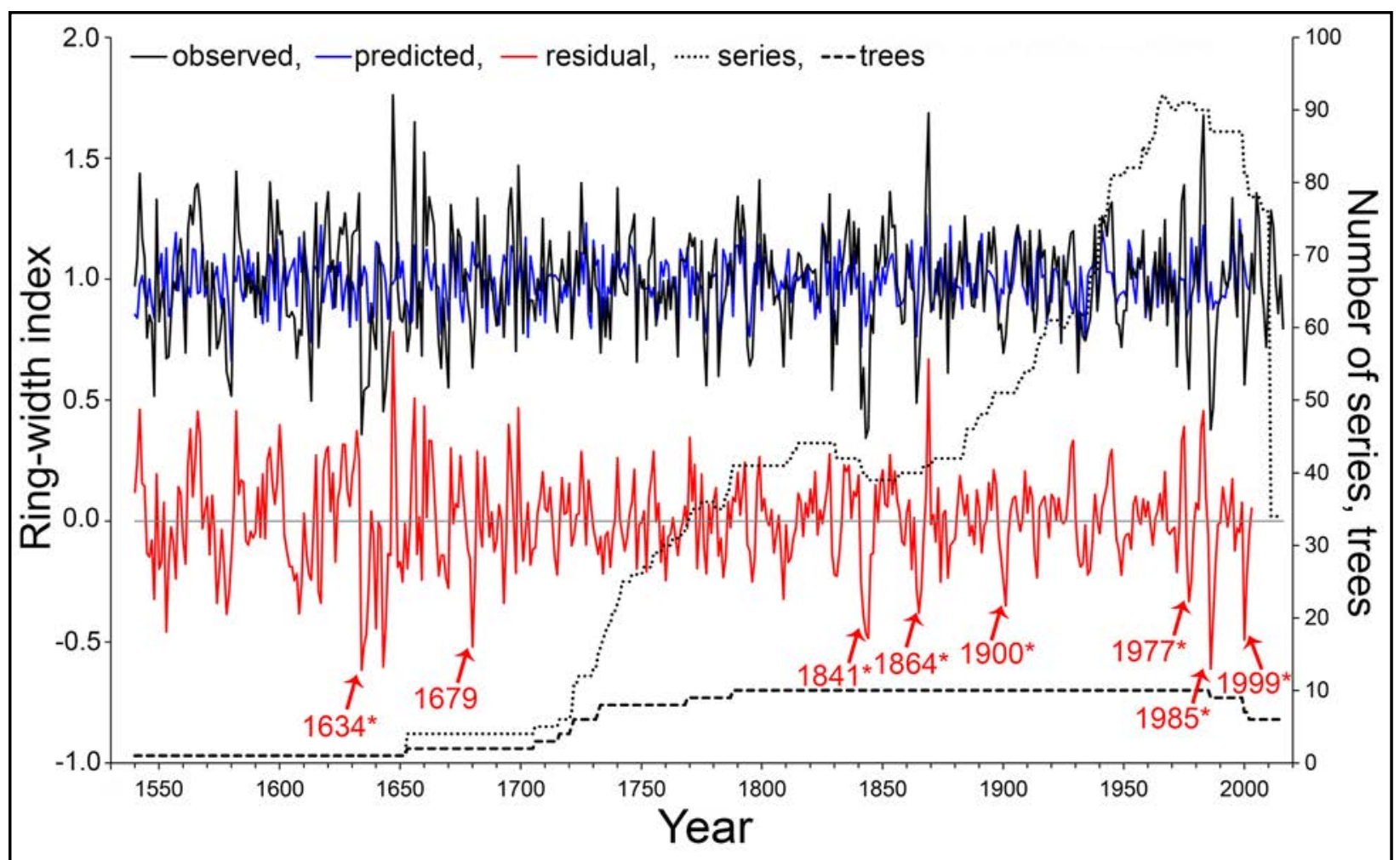

Figure 6. Ring-width index and sample depth for ten redwoods at Landels-Hill Big Creek Reserve (1540 to 2016) and potential fire years identified by post-event low growth relative to drought. Black line shows ring index from seven standing and three downed trees. Blue line shows predicted growth based on drought reconstruction. Red line shows residuals centered on zero. Red years identify potential fires and arrows point to low growth. Asterisks denote anatomical indicators observed on at least one series concurrent with event year.

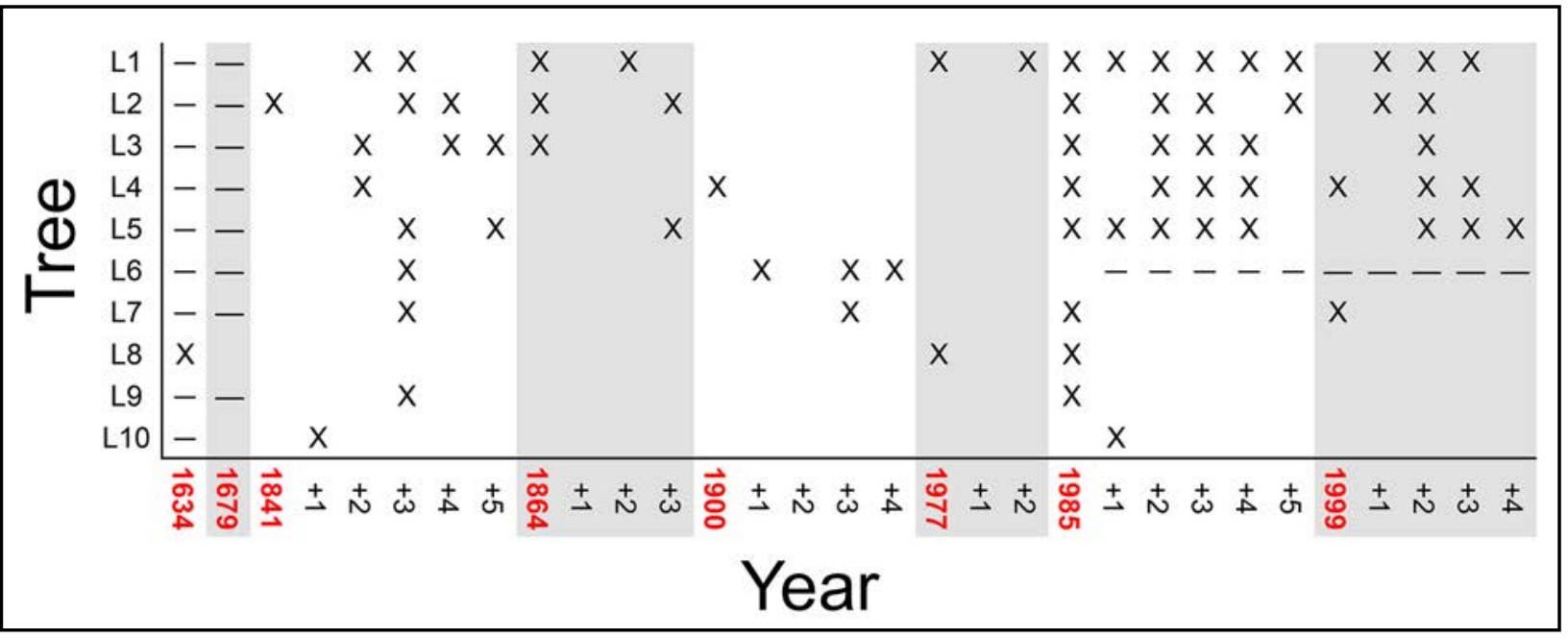

Figure 7. Presence of anatomical indicators associated with potential fire years for ten redwoods at Landels-Hill Big Creek Reserve. Potential fire years listed in red bold and identified by subsequent low radial growth relative to drought. $\mathrm{X}$ denotes indicator present on at least one series, blank denotes no indicators present, dash denotes year not sampled or crossdated. 


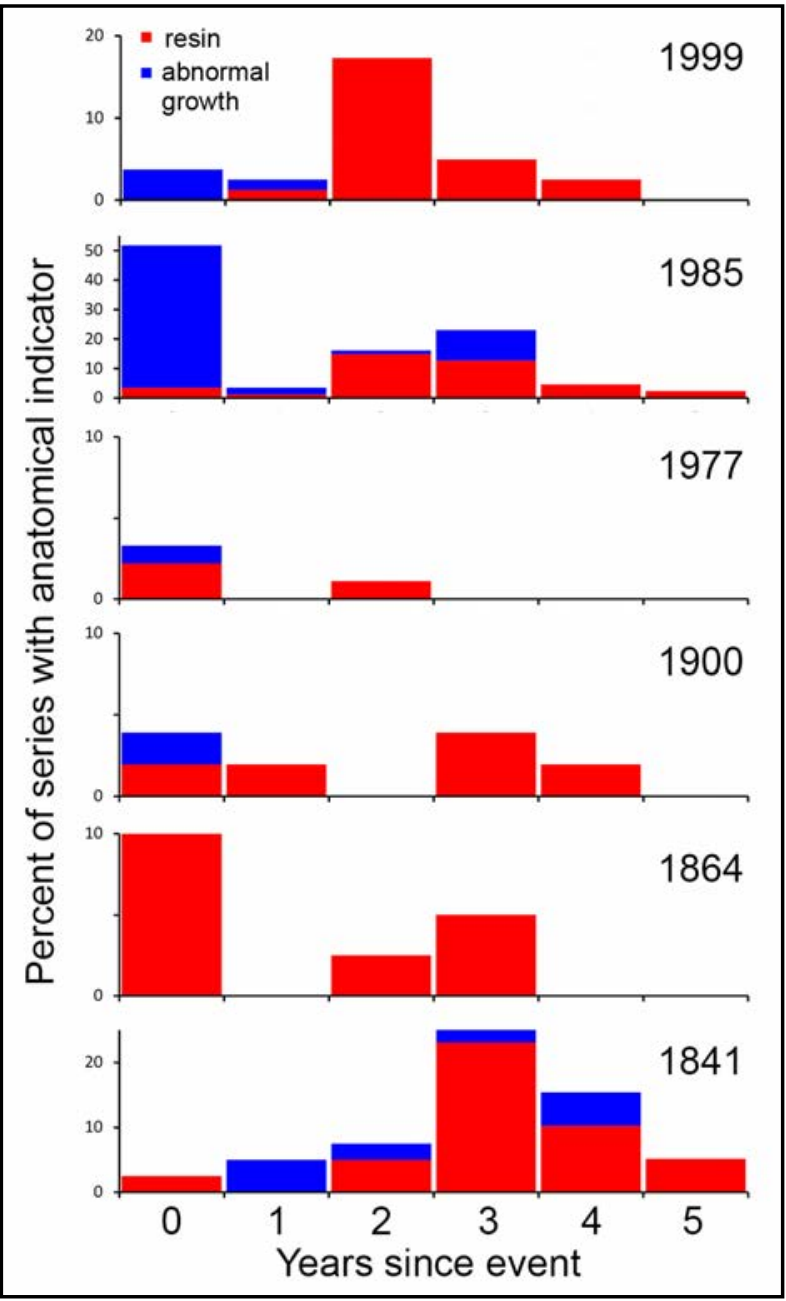

Figure 8. Percent of tree rings at Landels-Hill Big Creek Reserve with anatomical indicators for event year and five subsequent years for ten redwoods. Event year noted in upper right of each panel. Red denotes resin and blue denotes abnormal growth including intra-annual density fluctuations and faint latewood.

wood samples collected at multiple heights, considered climatic drivers of radial growth, and used these anomalies to detect potential fires over several centuries. Rather than relying on stumps and downed trees for samples, we utilized standing redwoods. This strategy provided replication needed for multi-century crossdating at the tree level and allowed living individuals to be used to supplement fire histories.
Fire triggers disruptions to normal cell formation as shown by IADFs, faint latewood, and resin. Fluctuations in earlywood (i.e., false rings) correspond with summer fires in 1985 and 2008, and demonstrate the potential for earlywood to resolve season of burn. Unlike study trees in Redwood National Park, in which double latewood occurs only with late-season fires (Brown and Swetnam 1994), IADFs in latewood follow June, July, and September fires. Faint latewood, a newly noted indicator for redwood, has similarities to light rings but is characterized only by lighter coloration of latewood without the additional component of few cell layers (Filion et al. 1986). Faint or thin cell-walled latewood likely corresponds with lower density (Wang et al. 2000), reflecting less available resources during the cell wall thickening phase. Trees can experience continued stress as narrow or missing rings often follow faint latewood and resin is produced for several years after fire. TRD in trees at Redwood National Park generally occur within one year of fire (Brown and Swetnam 1994), but also exist up to four years after fire (Swetnam 1987). IADFs and faint latewood can be attributed to several mechanisms, including defoliation, water stress, and constraining climatic conditions (Liang et al. 1997, De Micco et al. 2006, Liang and Eckstein 2006). Fire commonly occurs during drought, kills foliage, and affects water relations, so it is difficult to determine the exact cause of disrupted xylogenesis.

Heat from fires variably affects tree components, shifting the availability and allocation of resources. Post-fire reduction in radial growth points to depleted or diverted resources as trees react to damaged roots (Brown 1991, Swezy and Agee 1991), trunks (Seifert et al. 2017), or foliage (Douglas and Bendure 2012, Brown 2013). Trees may also be investing in basal sprouts at the expense of trunk wood production as they respond to disturbance (Brown and Swetnam 1994, Sawyer et al. 2000, Lazzeri-Aerts and Russell 2014, 


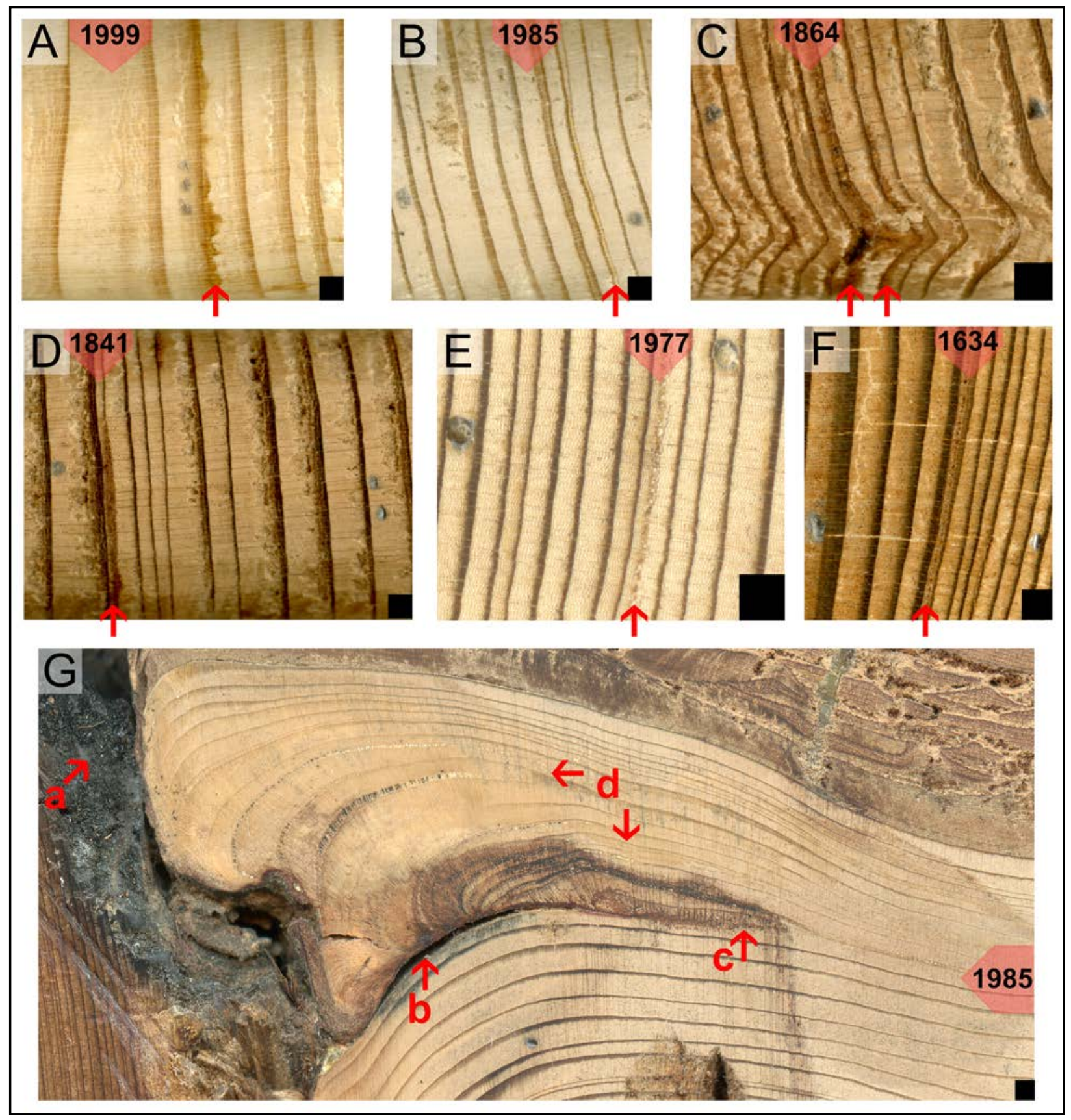

Figure 9. Anatomical indicators of known and suspected fires for redwoods at Landels-Hill Big Creek Reserve. Red boxes show year of event and red arrows point to indicators. Black boxes in lower right corners cover $1 \mathrm{~mm}^{2}$. Growth proceeds from left to right for A to F, and bottom to top for G. A) Traumatic resin ducts (TRD) and infused resin in the earlywood of 2001 at $70 \mathrm{~m}$; B) TRD in 1988 at $40 \mathrm{~m}$; C) TRD and infused resin in the latewood of 1864 and earlywood of 1866 at $10 \mathrm{~m}$; D) TRD in the latewood of 1841 at $40 \mathrm{~m}$; E) TRD in the latewood of 1977 at $3 \mathrm{~m}$; F) TRD in the earlywood of 1634 at $3 \mathrm{~m}$ for remnant; and G) scar from 1985 fire showing a) char, b) ring separation, c) mid-ring scar, d) TRD and discolored wood for subsequent growth rings. 
O'Hara et al. 2017). Basal sprouting in redwood can be triggered by fire, and ages of the resulting reiterated trunks approximate fire dates (Abbott 1987, Stuart 1987). Investment in sprouting may partially explain why redwood shows initial post-fire growth decreases, even in low-severity to moderate-severity fires, while its closest relative, the non-sprouting giant sequoia, expresses growth releases (Brown et al. 1992, Mutch and Swetnam 1995). Increased radial growth following suppressions for the 1985 and 1999 fires suggests a return on investment after trees rebuild their capacity and potentially benefit from neighboring tree injury or mortality. Such patterns may reflect recovery and crown optimization by redwoods after disturbance (Van Pelt et al. 2016).

As forests burn, the physiological responses of trees to stress or injury result from a combination of simultaneous processes, and fire behavior can vary from tree to tree. More frequent and robust indicators of the 1985 event suggest that fire severity and intensity affect tree responses. Post-fire measurements of char height, crown scorch, tree mortality, basal sprouting, and fire severity (e.g., Ramage et al. 2010, Lazzeri-Aerts and Russell 2014) coupled with increment cores collected several years later from standing redwoods could link growth and anatomical indicators to specific drivers. Although tree size may influence responsiveness to fire due to bark thickness (Sillett et al. 2015), epicormic sprouting (Abbott 1987), and ability to survive fire (Ramage et al. 2010, Douglas and Bendure 2012), no size-related trend in fire indicators is evident in this study of trees $93 \mathrm{~cm} f$-DBH to 481 $\mathrm{cm} f$-DBH. While individuals show varying degrees of radial growth and wood anatomy effects following the MW and LH events, sampling trees regardless of external signs of fire reliably capture tree-ring indicators when viewed in aggregate.

To further resolve redwood fire histories, we applied a detection method applicable to standing trees, broadening the scope of indi- viduals and forests available for study. Non-climatic growth suppression and anatomical indicators left a fingerprint in the tree-ring history revealing five additional events at LH. Since disturbances other than fire also cause reduced radial growth and atypical wood anatomy (Stoffel and Bollschweiler 2008), these dates isolate potential fire years and would ideally be used in combination with fire scars to document spatial extent. The inclusion of two samples outside of the plot provided evidence of the July 1977 Marble Cone Fire, which burned the nearby Ventana Wilderness. In 1841, fires burned forests in northern and central California (Skinner et al. 2009), and we infer that this regional event extends to the Big Sur coast. Declining sample depth limits the interpretation of results prior to the 1700s. The relationship between radial increment and fire should be considered if climate reconstructions are generated from redwoods. Reconstructions are likely for southern locations near $\mathrm{LH}$, where ring widths show strong sensitivities to drought (Carroll et al. 2014) and crossdated chronologies now extend to 1540.

Using anatomical and growth indicators captured by increment cores from standing trees provides a valuable tool for better resolving fire histories in the redwood region. A complementary methodology sampling both fire-scarred stumps and non-scar indicators from living trees would help to crossdate basal scars, further ascertain the applicability of the non-scar indicators (e.g., prior to fire-exclusion fuel buildups, under varying fire severities and seasons), and better quantify fire extent in redwood forests. A more robust understanding of redwood's fire regime remains a goal for improved conservation (Varner and Jules 2017) of the $7.1 \%$ of redwood forests that are large and complex (Cowan et al. 2017), as well as for promoting old-growth characteristics in young redwood forests (Engber et al. 2017). As we continue to expand the network of crossdated redwood tree-ring records (Carroll et al. 2017), we will utilize these methods to understand the role of fire in redwood forests. 


\section{ACKNOWLEDGEMENTS}

This research was supported by Save the Redwoods League's Redwoods and Climate Change Initiative and the Kenneth L. Fisher chair of Redwood Forest Ecology at Humboldt State University. We acknowledge the efforts of the field team: M. Antoine, J. Campbell-Spickler, E. Coonen, J. Freund, R. Kramer, G. Renzullo, and K. Scarla. We thank J. Kane for help categorizing resin on core samples, P. Cowan for acquiring PRISM climate data, F. Arias for contributing remnant samples, and an associate editor and two anonymous reviewers for insightful suggestions to the text. We thank the California Department of Parks and Recreation and the University of California for permission to work in MW and LH, respectively.

\section{LITERATURE CITED}

Abbott, L.L. 1987. The effect of fire on subsequent growth of surviving trees in an old growth redwood forest in Redwood National Park, CA. Thesis, Humboldt State University, Arcata, California, USA.

Anderson, M.K. 2005. Tending the wild: Native American knowledge and the management of California's natural resources. University of California Press, Berkeley, USA.

Arno, S.F., and K.M. Sneck. 1977. A method for determining fire history in coniferous forest of the mountain West. USDA Forest Service General Technical Report INT-42, Intermountain Forest and Range Experiment Station, Ogden, Utah, USA.

Bigio, E.R., T.W. Swetnam, and C.H. Baisan. 2015. Local-scale and regional climate controls on historical fire regimes in the San Juan Mountains, Colorado. Forest Ecology and Management 360: 311-322. doi: 10.1016/j.foreco.2015.10.041

Brown, P.M. 1991. Dendrochronology and fire history in a stand of northern California coast redwood. Thesis, The University of Arizona, Tucson, USA.

Brown, P.M., M.K. Hughes, C.H. Baisan, T.W. Swetnam, and A.C. Caprio. 1992. Giant sequoia ring-width chronologies from the central Sierra Nevada, California. Tree-Ring Bulletin 52: $1-14$.

Brown, P.M., and T.W. Swetnam. 1994. A cross-dated fire history from coast redwood near Redwood National Park, California. Canadian Journal of Forest Research 24: 21-31. doi: 10.1139/x94-004

Brown, P.M., and W.T. Baxter. 2003. Fire history in coast redwood forests of the Mendocino Coast, California. Northwest Science 77: 147-158

Brown, P.M. 2013. Dendrochronology, fire regimes. Pages 204-207 in: W.J. Rink and J.W. Thompson, editors. Encyclopedia of scientific dating methods. Springer, Dordrecht, The Netherlands. doi: 10.1007/978-94-007-6326-5_76-4

Burgess, S.S.O., and T.E. Dawson. 2004. The contribution of fog to the water relations of Sequoia sempervirens (D. Don): foliar uptake and prevention of dehydration. Plant, Cell \& Environment 27: 1023-1034. doi: 10.1111/j.1365-3040.2004.01207.x

CAL FIRE [California Department of Forestry and Fire Protection]. 2008. 2008 June fire siege. $<$ http://www.fire.ca.gov/fire_protection/fire_protection_2008_siege $>$. Accessed 1 February 2017.

Caprio, A.C., L.S. Mutch, T.W. Swetnam, and C.H. Baisan. 1994. Temporal and spatial patterns of giant sequoia radial growth response to a high severity fire in A.D. 1297. Final report to California Department of Forest and Fire Protection No. 8CA17025, Mountain Home State Forest, Springville, California, USA. 
Carroll, A.L., S.C. Sillett, and R.D. Kramer. 2014. Millennium-scale crossdating and inter-annual climate sensitivities of standing California redwoods. PLoS ONE 9: 1-18. doi: 10.1371/ journal.pone.0102545

Carroll, A.L., S.C. Sillett, E.J. Coonen, and B.G. Iberle. 2017. Expanding the network of crossdated tree-ring chronologies for Sequoia sempervirens. Pages 25-33 in: R.B. Standiford and Y. Valachovic, technical coordinators. Proceedings of the Coast Redwood Science Symposium. USDA Forest Service General Technical Report PSW-GTR-258, Pacific Southwest Research Station, Albany, California, USA.

Cook, E.R. 1985. A time series analysis approach to tree-ring standardization. Dissertation, The University of Arizona, Tucson, USA.

Cook, E.R., and P.J. Krusic. 2004. The North American drought atlas. Lamont-Doherty Earth Observatory and the National Science Foundation. <http://iridl.ldeo.columbia.edu/SOURCES/.LDEO/.TRL/.NADA2004/.pdsi-atlas.html>. Accessed 29 March 2017.

Cowan, P., E.E. Burns, and R. Campbell. 2017. A GIS approach to identifying the distribution and structure of coast redwood across its range. Pages 357-359 in: R.B. Standiford and Y. Valachovic, technical coordinators. Proceedings of the Coast Redwood Science Symposium. USDA Forest Service General Technical Report PSW-GTR-258, Pacific Southwest Research Station, Albany, California, USA.

Dai, A., K.E. Trenberth, and T. Qian. 2004. A global dataset of Palmer Drought Severity Index for 1870-2002: relationship with soil moisture and effects of surface warming. Journal of Hydrometeorology 5: 1117-1130. doi: 10.1175/JHM-386.1

Dawson, T.D. 1998. Fog in the California redwood forest: ecosystem inputs and use by plant. Oecologia 117: 476-485. doi: 10.1007/s004420050683

De Micco, V., F. Campelo, M. De Luis, A. Bräuning, M. Grabner, G. Battipaglia, and P. Cherubini. 2016. Intra-annual density fluctuations in tree rings: how, when, where, and why? IAWA Journal 37: 232-259. doi: 10.1163/22941932-20160132

Douglas, R.B., and T. Bendure. 2012. Post-fire response of coast redwood one year after the Mendocino Lightning Complex Fires. USDA Forest Service General Technical Report PSWGTW-238, Pacific Southwest Research Station, Albany, California, USA.

Engber, E., J. Teraoka, and P. van Mantgem. 2017. Forest restoration at Redwood National Park: exploring prescribed fire alternatives to second-growth management: a case study. Pages 7886 in: R.B. Standiford and Y. Valachovic, technical coordinators. Proceedings of the Coast Redwood Science Symposium. USDA Forest Service General Technical Report PSWGTR-258, Pacific Southwest Research Station, Albany, California, USA.

Filion, L., S. Payette, L. Gauthier, and Y. Boutin. 1986. Light rings in subarctic conifers as a dendrochronological tool. Quaternary Research 26: 272-279. doi: 10.1016/0033-5894(86) 90111-0

Fritz, E., and J.L. Averill. 1924. Discontinuous growth rings in California redwood. Journal of Forestry 22: 31-38.

Fritz, E. 1931. The role of fire in the redwood region. Journal of Forestry 29: 939-950.

Fritz, E. 1940. Problems in dating rings of California coast redwood. Tree-Ring Bulletin 6: 19-21.

Greenlee, J.M., and J.H. Langenheim. 1990. Historic fire regimes and their relation to vegetation patterns in the Monterey Bay area of California. The American Midland Naturalist 124: 239253. doi: $10.2307 / 2426173$

Gripp, R.A. 1976. An appraisal of critical fire weather in northwestern California. Thesis, Humboldt State University, California, USA. 
Hartesveldt, R.J. 1964. The fire ecology of the giant sequoias. Natural History Magazine 73: 12-19.

Heyerdahl, E.K., L.B. Brubaker, and J.K. Agee. 2001. Spatial controls of historical fire regimes: a multiscale example from the interior West, USA. Ecology 82: 660-678. doi: 10.1890/0012-9658(2001)082[0660:SCOHFR]2.0.CO;2

Holmes, R.L. 1983. Computer-assisted quality control in tree-ring dating and measurement. Tree-Ring Bulletin 43: 69-75.

Holz, A., and T.T. Veblen. 2009. Pilgerodendron uviferum: the southernmost tree-ring fire recorder species. Ecoscience 16: 322-329. doi: 10.2980/16-3-3262

Hudgins, J.W., E. Christiansen, and V.R. Franceschi. 2004. Induction of anatomically based defense responses in stems of diverse conifers by methyl jasmonate: a phylogenetic perspective. Tree Physiology 24: 251-264. doi: 10.1093/treephys/24.3.251

Iacobellis, S.F., and D.R. Cayan. 2013. The variability of California summertime marine stratus: impacts on surface air temperatures. Journal of Geophysical Research 118: 9105-9122. doi: 10.1002/jgrd.50652

Jacobs, D.F., D.W. Cole, and J.R. McBride. 1985. Fire history and perpetuation of natural coast redwood ecosystems. Journal of Forestry 83: 494-497.

Jones, G.A., and W. Russell. 2015. Approximation of fire-return intervals with point samples in the southern range of the coast redwood forest, California, USA. Fire Ecology 11(3): 80-94. doi: 10.4996/fireecology.1103080

Krokene, P., N.E. Nagy, and T. Krekling. 2008. Traumatic resin ducts and polyphenolic parenchyma cells in conifers. Pages 147-169 in: A. Schaller, editor. Induced plant resistance to herbivory. Springer, Dordrecht, The Netherlands. doi: 10.1007/978-1-4020-8182-8_7

Lazzeri-Aerts, R., and W. Russell. 2014. Survival and recovery following wildfire in the southern range of the coast redwood forest. Fire Ecology 10(1): 43-55. doi: 10.4996/fireecology.1001043

Liang, C., L. Filion, and L. Cournoyer. 1997. Wood structure of biotically and climatically induced light rings in eastern larch (Larix laricina). Canadian Journal of Forest Research 27: 1538-1547. doi: 10.1139/x97-117

Liang, E., and D. Eckstein. 2006. Light rings in Chinese pine (Pinus tabulaeformis) in semiarid areas of north China and their paleo-climatological potential. New Phytologist 171: 783791. doi: 10.1111/j.1469-8137.2006.01775.x

Lombardo, K.J., T.W. Swetnam, C.H. Baisan, and M.I. Borchert. 2009. Using bigcone Douglas-fir fire scars and tree rings to reconstruct interior chaparral fire history. Fire Ecology 5(3): 35-56. doi: 10.4996/fireecology.0503035

Lorimer, C.G., D.J. Porter, M.A. Madej, J.D. Stuart, S.D.J. Veirs, S.P. Norman, K.L. O'Hara, and W.J. Libby. 2009. Presettlement and modern disturbance regimes in coast redwood forests: implications for the conservation of old-growth stands. Forest Ecology and Management 258: 1038-1054. doi: 10.1016/j.foreco.2009.07.008

Margolis, E.Q., T.W. Swetnam, and C.D. Allen. 2011. Historical stand-replacing fire in upper montane forests of the Madrean Sky Islands and Mogollon Plateau, southwestern USA. Fire Ecology 7(3): 88-107. doi: 10.4996/fireecology.0703088

McBride, J.R. 1983. Analysis of tree-rings and fire scars to establish fire history. Tree-Ring Bulletin 43: 51-68.

Mutch, L.S. 1994. Growth responses of giant sequoia to fire and climate in Sequoia and Kings Canyon National Parks, California. Thesis, The University of Arizona, Tucson, USA. 
Mutch, L.S., and T.W. Swetnam. 1995. Effects of fire severity and climate on ring-width growth of giant sequoia after burning. Pages 241-246 in: J.K. Brown, R.W. Mutch, C.W. Spoon, and R.H. Wakimoto, technical coordinators. Proceedings of symposium on fire in wilderness and park management. USDA Forest Service General Technical Report INT-320, Intermountain Research Station, Ogden, Utah, USA.

NOAA [National Oceanic and Atmospheric Administration]. 2017. International Tree-Ring Data Bank. <https://www.ncdc.noaa.gov/data-access/paleoclimatology-data/datasets/tree-ring>. Accessed 23 March 2017.

Norman, S.P., J.M. Varner, L. Arguello, S. Underwood, B. Graham, G. Jennings, Y. Valachovic, and C. Lee. 2009. Fire and fuels management in coast redwood forests. JFSP Research Project Reports Paper 158 Project 06-2-1-59, US Joint Fire Science Program, Boise, Idaho, USA.

O’Hara, K.L., L.E. Cox, S. Nikolaeva, J.J. Bauer, and R. Hedges. 2017. Regeneration dynamics of coast redwood, a sprouting conifer species: a review with implications for management and restoration. Forests 8: 144-162. doi: 10.3390/f8050144

PRISM Climate Group. 2016. Northwest Alliance for Computational Science and Engineering at Oregon State University. PRISM climate data. <http://prism.oregonstate.edu>. Accessed 14 October 2016.

Py, C., J. Bauer, P.J. Weisberg, and F. Biondi. 2006. Radial growth responses of singleleaf pinyon (Pinus monophylla) to wildfire. Dendrochronologia 24: 39-46. doi: 10.1016/j.dendro. 2006.05.003

Ramage, B.S., K.L. O'Hara, and B.T. Caldwell. 2010. The role of fire in the competitive dynamics of coast redwood forests. Ecosphere 1: 1-18. doi: 10.1890/ES10-00134.1

Sawyer, J.O., S.C. Sillett, W.J. Libby, T.E. Dawson, J.H. Popenoe, D.L. Largent, R. Van Pelt, S.D. Veirs Jr., R.F. Noss, D.A. Thornburgh, and P. Del Tredici. 2000. Redwood trees, communities, and ecosystems: a closer look. Pages 81-118 in: R.F. Noss, editor. The Redwood Forest. Island Press, Washington, D.C., USA.

Seifert, T., M. Meincken, and B.O. Odhiambo. 2017. The effect of surface fire on tree ring growth of Pinus radiata trees. Annals of Forest Science 74: 1-11. doi: 10.1007/ s13595-016-0608-8

Sillett, S.C., R. Van Pelt, G.W. Koch, A.R. Ambrose, A.L. Carroll, M.E. Antoine, and B.M. Mifsud. 2010. Increasing wood production through old age in tall trees. Forest Ecology and Management 259: 976-994. doi: 10.1016/j.foreco.2009.12.003

Sillett, S.C., R. Van Pelt, A.L. Carroll, R.D. Kramer, A.R. Ambrose, and D. Trask. 2015. How do tree structure and old age affect growth potential of California redwoods? Ecological Monographs 85: 181-212. doi: 10.1890/14-1016.1

Skinner, C.N., C.S. Abbott, D.L. Fry, S.L. Stephens, A.H. Taylor, and V. Trouet. 2009. Human and climatic influences on fire occurrence in California's North Coast Range, USA. Fire Ecology 5(3): 76-99. doi: 10.4996/fireecology.0503076

Smith, K.T., E. Arbellay, D.A. Falk, and E.K. Sutherland. 2016. Macroanatomy and compartmentalization of recent fire scars in three North American conifers. Canadian Journal of Forest Research 46: 535-542. doi: 10.1139/cjfr-2015-0377

Stahle, D.W., R.D. Griffin, D.M. Meko, M.D. Therrell, J.R. Edmondson, M.K. Cleaveland, L.N. Stahle, D.J. Burnette, J.T. Abatzoglou, K.T. Redmond, M.D. Dettinger, and D.R. Cayan. 2013. The ancient blue oak woodlands of California: longevity and hydroclimatic history. Earth Interactions 17: 1-23. doi: 10.1175/2013EI000518.1

Stephens, S.L., and D.L. Fry. 2005. Fire history in coast redwood stands in the northeastern Santa Cruz Mountains, California. Fire Ecology 1(1): 2-19. doi: 10.4996/fireecology.0101002 
Stoffel, M., and M. Bollschweiler. 2008. Tree-ring analysis in natural hazards research—an overview. Natural Hazards and Earth System Sciences 8: 187-202. doi: 10.5194/ nhess-8-187-2008

Stuart, J.D. 1987. Fire history of an old-growth forest of Sequoia sempervirens (Taxodiaceae) forest in Humboldt Redwoods State Park, California. Madroño 34: 128-141.

Stuart, J.D., and S.L. Stephens. 2006. North Coast Bioregion. Pages 147-169 in: N.G. Sugihara, J.W. van Wagtendonk, K.E. Shaffer, J. Fites-Kaufman, and A.E. Thode, editors. Fire in California's ecosystems. University of California Press, Berkeley, USA. doi: 10.1525/ california/9780520246058.003.0008

Swetnam, T.W. 1987. Fire history and dendroclimatic studies in coast redwood. Final report to Redwood National Park No. 8480-6-0875, Orick, California, USA.

Swetnam, T.W., R. Touchan, C.H. Baisan, A.C. Caprio, and P.M. Brown. 1991. Giant sequoia fire history in Mariposa Grove, Yosemite National Park. Pages 249-255 in: J. Edelbrock and S. Carpenter, coordinators. Proceedings of the Yosemite Centennial Symposium-natural areas and Yosemite: prospects for the future. Yosemite Association, 13-20 October 1990, El Portal, California, USA.

Swetnam, T.W. 1993. Fire history and climate change in giant sequoia groves. Science 262: 885-889. doi: 10.1126/science.262.5135.885

Swetnam, T.W., C.H. Baisan, A.C. Caprio, P.M. Brown, R. Touchan, R.S. Anderson, and D.J. Hallett. 2009. Multi-millennial fire history of the Giant Forest, Sequoia National Park, California, USA. Fire Ecology 5(3): 120-150. doi: 10.4996/fireecology.0503120

Swezy, D.M., and J.K. Agee. 1991. Prescribed-fire effects on fine-root and tree mortality in oldgrowth ponderosa pine. Canadian Journal of Forest Research 21: 626-634. doi: 10.1139/ x91-086

USGS [United States Geological Survey]. 2016. Monitoring Trends in Burn Severity project data access: individual fire-level geospatial data. <http://mtbs.gov/data/individualfiredata. html>. Accessed 14 January 2016.

Van Pelt, R., S.C. Sillett, W.A. Kruse, J.A. Freund, and R.D. Kramer. 2016. Emergent crowns and light-use complementarity lead to global maximum biomass and leaf area in Sequoia sempervirens forests. Forest Ecology and Management 375: 279-308. doi: 10.1016/j.foreco.2016.05.018

Varner, J.M., and E.S. Jules. 2017. The enigmatic fire regime of coast redwood forests and why it matters. Pages 15-18 in: R.B. Standiford and Y. Valachovic, technical coordinators. Proceedings of the Coast Redwood Science Symposium. USDA Forest Service General Technical Report PSW-GTR-258, Pacific Southwest Research Station, Albany, California, USA.

Vieira, J., F. Campelo, and C. Nabais. 2010. Intra-annual density fluctuations of Pinus pinaster are a record of climatic changes in the western Mediterranean region. Canadian Journal of Forest Research 40: 1567-1575. doi: 10.1139/X10-096

Wang, L., S. Payette, and Y. Bégin. 2000. A quantitative definition of light rings in black spruce (Picea mariana) at the Arctic treeline in northern Québec, Canada. Arctic, Antarctic, and Alpine Research 32: 324-330. doi: 10.2307/1552531

Western Regional Climate Center. 2017. WestWide Drought Tracker. <http://www.wrcc.dri. edu>. Accessed 9 March 2017. 